AL.2.2003.211

cid

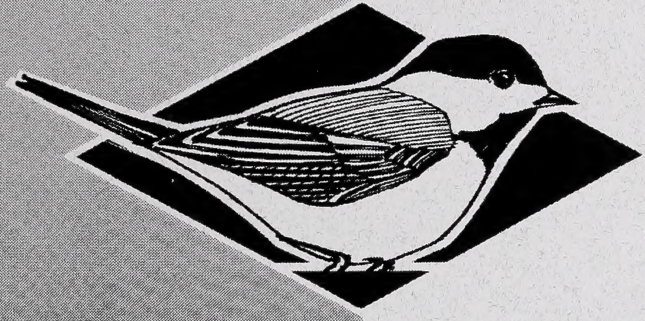

Status of the

Small-flowered Sand Verbena

(Tripterocalyx micranthus)

in Alberta

Fish \& Wildifie

Division

BODWERSITY AND

SPECIES AT RISK SECTION

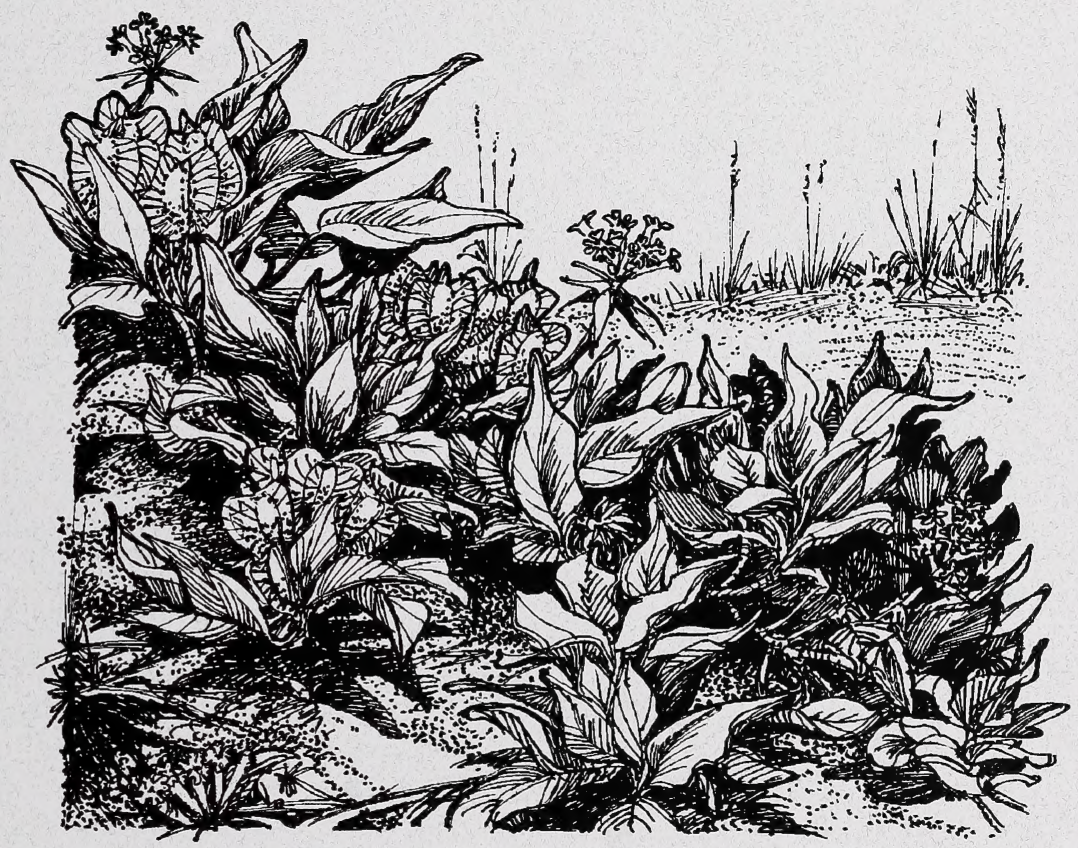

Alberta Wildlife Status Report No. 48

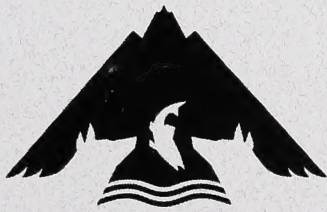

Alberta Conservation Association 


\title{
Status of the Small-flowered Sand Verbena (Tripterocalyx micranthus) in Alberta
}

\author{
Prepared for:
}

Alberta Sustainable Resource Development (SRD)

Alberta Conservation Association (ACA)

Prepared by:

\section{Bonnie Smith}

This report has been reviewed, revised, and edited prior to publication. It is an SRD/ACA working document that will be revised and updated periodically.

Alberta Wildlife Status Report No. 48

May 2003

Published By:

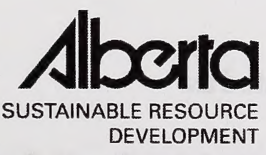

Fish \& Wildlife

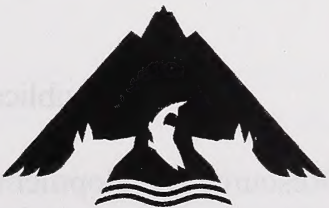

Alberta Conservation Association 
Publication No. T/046

ISBN: 0-7785-2915-0 (Printed Edition)

ISBN: 0-7785-2916-9 (On-line Edition)

ISSN: 1206-4912 (Printed Edition)

ISSN: 1499-4682 (On-line Edition)

Series Editors: Sue Peters and Robin Gutsell

Illustrations: Brian Huffman

Maps: Jane Bailey

For copies of this report,visit our web site at :

http://www3.gov.ab.ca/srd/fw/riskspecies/

and click on "Detailed Status"

$O R$

Contact:

Information Centre - Publications

Alberta Environment/Alberta Sustainable Resource Development

Fish and Wildlife Division

Main Floor, Great West Life Building

9920 - 108 Street

Edmonton, Alberta, Canada T5K 2M4

Telephone: (780) 422-2079

OR

Information Service

Alberta Environment/Alberta Sustainable Resource Development \#100, 3115 - 12 Street NE

Calgary, Alberta, Canada T2E 7J2

Telephone: (403) 297-6424

This publication may be cited as:

Alberta Sustainable Resource Development. 2003. Status of the Small-flowered Sand Verbena

(Tripterocalyx micranthus) in Alberta. Alberta Sustainable Resource Development, Fish and Wildlife Division, and Alberta Conservation Association, Wildlife Status Report No. 48, Edmonton, AB. 24 pp. 


\section{PREFACE}

Every five years, the Fish and Wildlife Division of Alberta Sustainable Resource Development reviews the status of wildlife species in Alberta. These overviews, which have been conducted in 1991, 1996 and 2000, assign individual species "ranks" that reflect the perceived level of risk to populations that occur in the province. Such designations are determined from extensive consultations with professional and amateur biologists, and from a variety of readily available sources of population data. A primary objective of these reviews is to identify species that may be considered for more detailed status determinations.

The Alberta Wildlife Status Report Series is an extension of the general statusing exercises (1996 Status of Alberta Wildlife, The General Status of Alberta Wild Species 2000), and provides comprehensive current summaries of the biological status of selected wildlife species in Alberta. Priority is given to species that are potentially at risk in the province ("At Risk," "May Be At Risk"), that are of uncertain status ("Undetermined"), or those considered to be at risk at a national level by the Committee on the Status of Endangered Wildlife in Canada (COSEWIC).

Reports in this series are published and distributed by the Alberta Conservation Association and the Fish and Wildlife Division of Alberta Sustainable Resource Development. They are intended to provide detailed and up-to-date information which will be useful to resource professionals for managing populations of species and their habitats in the province. The reports are also designed to provide current information which will assist the Alberta Endangered Species Conservation Committee to identify species that may be formally designated as "Endangered" or "Threatened" under Alberta's Wildlife Act. To achieve these goals, the reports have been authored and/or reviewed by individuals with unique local expertise in the biology and management of each species. 


\section{EXECUTIVE SUMMARY}

Within Canada, small-flowered sand verbena (Tripterocalyx micranthus (Torr.) Hook.) is primarily distributed in southeastern Alberta (eight general locations containing a total of 15 sites). As well, the species occurs at one site just east of the Alberta border in southern Saskatchewan. Otherwise, smallflowered sand verbena is confined in the wild to the western United States. Small-flowered sand verbena is considered "May Be At Risk" in Alberta, according to the General Status 2000 exercise conducted by Alberta Sustainable Resource Development (Alberta Sustainable Resource Development, unpubl. report), and it is ranked S2 by the Alberta Natural Heritage Information Centre. In 1992, the Committee on the Status of Endangered Wildlife in Canada (COSEWIC) designated the species as "Threatened." This designation was reviewed and upgraded to "Endangered" in 2002. This report summarizes the existing information on small-flowered sand verbena in Alberta to assist with the assessment of its status.

In Alberta, small-flowered sand verbena is known from eight general locations: Lost River, Purple Springs, Grassy Lake, Wolf Island, Lower Bow, North of Medicine Hat, North of Medicine Hat Suffield and Suffield National Wildlife Area. Some general locations contain multiple sites and subsites. In 2002, new small-flowered sand verbena sites were located at Purple Springs (Site 5, 269 plants), Grassy Lake (Site 6, 1797 plants), Lower Bow (Site 11, 789 plants), North of Medicine Hat (Site 12, 99 plants) and North of Medicine Hat Suffield (Site 14, 1 plant). The total population of the four sites surveyed during the 2002 field season was 2955 plants. In past years, small-flowered sand verbena has been located at Lost River (Sites 1-3, 200 plants estimated), Purple Springs (Site 4, 30 plants), Wolf Island (Site 7, 110 plants), Lower Bow (Sites 8-10, 265 plants), North of Medicine Hat (Site 13, fewer than 100 plants) and Suffield National Wildlife Area (Site 15, 1 plant). The number of plants at any particular site may vary substantially from year to year. The total population estimated in 2002 for all Alberta sites is 3600 plants, which likely represents a maximum along a wide continuum of population sizes for sand verbena in Alberta.

Small-flowered sand verbena sites are typically small in size, not exceeding $100 \mathrm{~m}^{2}$. Population numbers can change dramatically from year to year based on climatic conditions, in particular, moisture levels. In 2001 the Lower Bow site contained 1 plant, while in 2002 the same site contained 789 plants. Smallflowered sand verbena is an ephemeral annual species, which, in good years, produces masses of seeds that remain viable in the sandy seed bank until a future growing season with suitable climatic conditions.

Small-flowered sand verbena is found in dry habitats, particularly in loose sands of dune and sandhill areas. Some element of active sand is usually required. The largest populations are on hard-packed finer sand on level terrain, but it also occurs on south-, west-, and east-facing slopes and along dune ridge tops. Most sites are on the uplands, but the species may also occur in the valleys of the Lost and South Saskatchewan rivers where sand dunes extend down into the valleys. It is restricted to the Dry Mixedgrass Subregion of the Grassland Natural Region, an area that has undergone extensive modification from its natural state by human activity.

Limiting factors of concern include dune stabilization, changes in land use and invasion of weedy species. The Grassy Lake site, containing more than half of the plant's Alberta population, is currently under threat as a result of sand removal and levelling of the main dune area. Considerable work on management strategies and status assessment should be undertaken as soon as possible as a means of maintaining the presence of this species in Alberta. 


\section{ACKNOWLEDGEMENTS}

The assistance of several people in the writing of this report is gratefully acknowledged: Clifford Wallis (Cottonwood Consultants, Calgary) for his work on sandy areas of Alberta and for his helpful comments on the Lost River site; Garry Trottier (Canadian Wildlife Service, Edmonton) for his site data on the north of Medicine Hat Suffield site; Candace Elchuk (Nature Saskatchewan, Regina) for her data on the Saskatchewan site; Robin Gutsell (Alberta Sustainable Resource Development, Edmonton), Andrew Didiuk (Environment Canada, Saskatoon), and Susan Peters (Alberta Conservation Association, Edmonton) for their office support and editorial assistance; Ian Macdonald (Botanical consultant, Terre Haute, Indiana) and Sheila Smith for their field assistance and photographic contributions and Ian Macdonald, as well, for his comments on the Suffield National Wildlife Area site. Terry Hood (Public Land Specialist, Agriculture, Food and Rural Development, Medicine Hat) provided insight on land management practices in sandy habitats. The editorial input of reviewers Joyce Gould (University of Alberta, Edmonton) and Ksenija Vujnovic (Alberta Natural Heritage Information Centre, Edmonton) is also gratefully acknowledged.

The Alberta Natural Heritage Information Centre (ANHIC, Alberta's Conservation Data Centre, or CDC) and Saskatchewan Rare Plants Data Base have provided information that has greatly assisted in the production of this report.

Preparation of this report was funded by the Alberta Conservation Association and the Fish and Wildlife Division of Alberta Sustainable Resource Development. 
Digitized by the Internet Archive in 2016 


\section{TABLE OF CONTENTS}

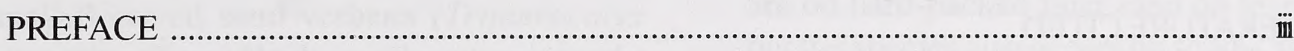

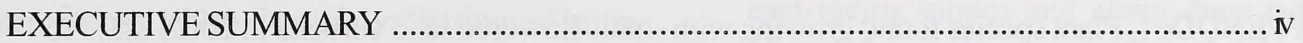

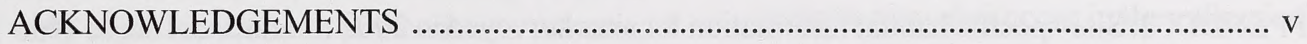

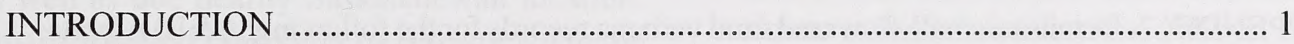

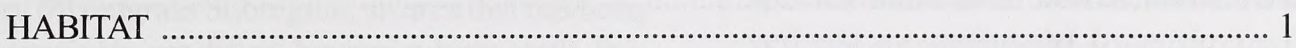

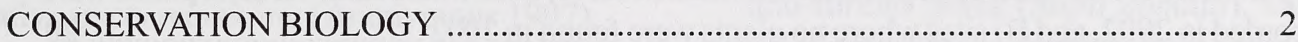

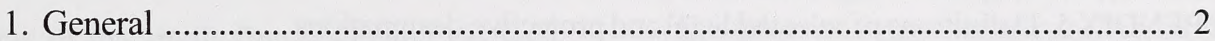

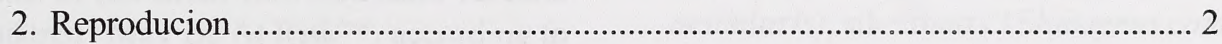

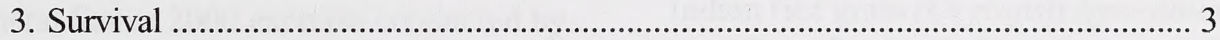

4. Movements/Dispersal ...................................................................................... 4

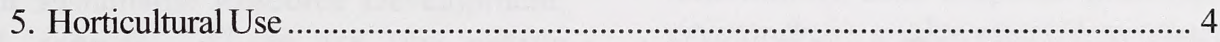

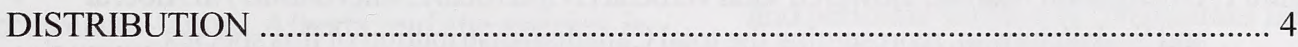

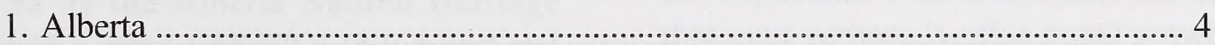

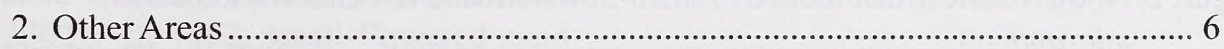

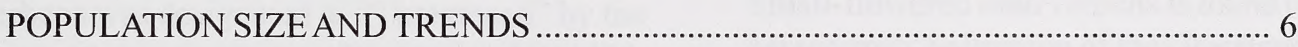

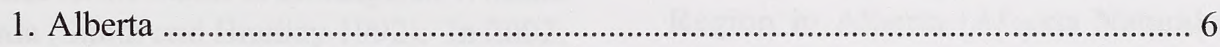

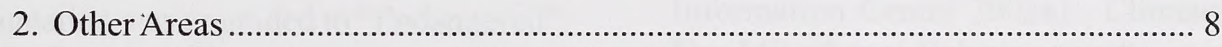

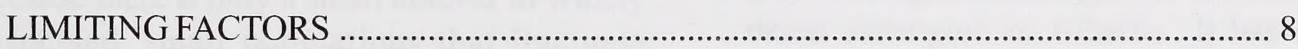

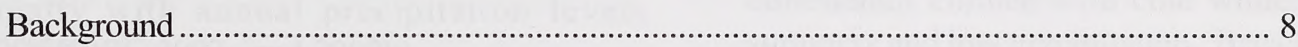

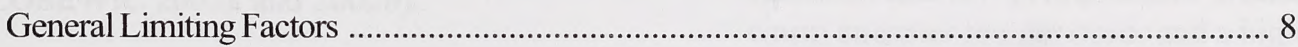

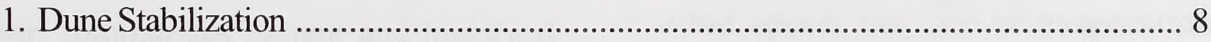

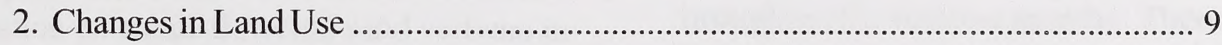

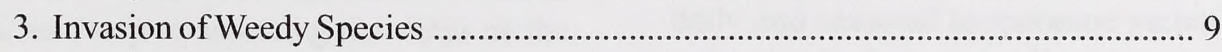

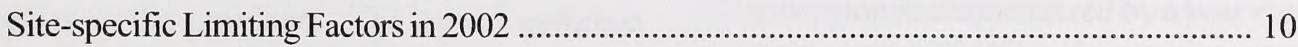

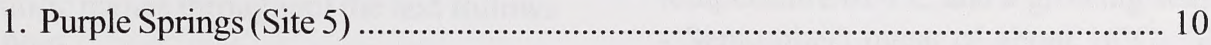

2. Grassy Lake (Site 6) ................................................................................... 10

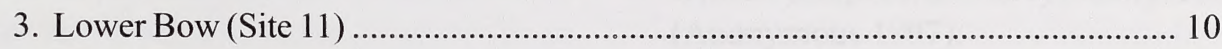

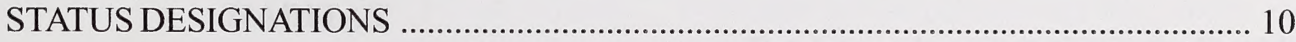

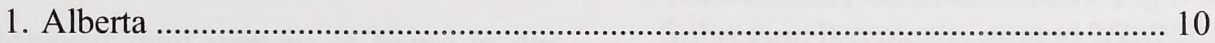

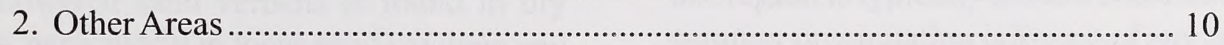

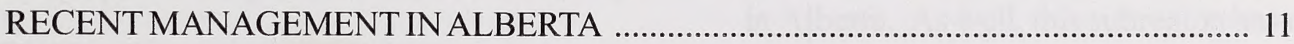

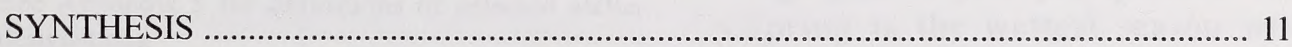




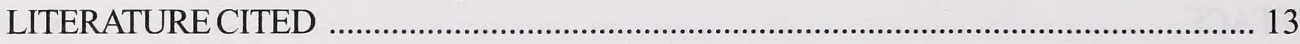

APPENDIX 1. Plant species found growing with small-flowered sand verbena in 2002 ....... 15

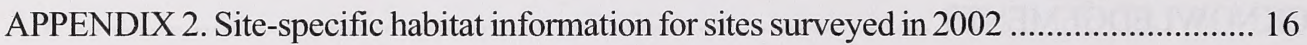

APPENDIX 3. Details of small-flowered sand verbena records for the following: A\&B) Alberta, and C) Saskatchewan.

APPENDIX 4. Site-specific population information for A) sites where sand verbena plants were

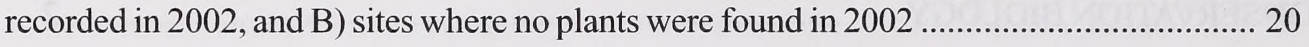

APPENDIX 5. Definitions of selected legal and protective designations ............................... 23

\section{LIST OF FIGURES}

Figure 1. Distribution of small-flowered sand verbena (Tripterocalyx micranthus) in Alberta and Saskatchewan, representing the total Canadian distribution of this species.......... 5

Figure 2. North American distribution of small-flowered sand verbena (Tripterocalyx micranthus) 


\section{INTRODUCTION}

Small-flowered sand verbena (Tripterocalyx micranthus (Torr.) Hook., or Abronia micrantha Torr. (Moss 1994), is widely distributed in the western United States, but in Canada, is found at only eight locations in southeastern Alberta, as well as one nearby Saskatchewan location. Small-flowered sand verbena is restricted to the Dry Mixedgrass Subregion, an area that has been extensively modified by agriculture with few native tracts remaining (Anonymous 1997).

The status of the small-flowered sand verbena is considered "May Be At Risk"*, according to the General Status 2000 exercise conducted by Alberta Sustainable Resource Development (Alberta Sustainable Resource Development, unpubl. report). There are few native occurrences within Alberta and the species is ranked S2 by the Alberta Natural Heritage Information Centre (ANHIC) (Vujnovic and Gould 2002). In 1992, small-flowered sand verbena was designated as "Threatened" by the Committee on the Status of Endangered Wildlife in Canada (Smith and Bradley 1992). In 2002, the designation was upgraded to "Endangered", because there is only a small number of widely dispersed, small populations that fluctuate greatly with annual precipitation levels (COSEWIC 2002a and 2002b).

This report summarizes current and historical information on small-flowered sand verbena in Alberta, as a step to assessing the status of the species in the province. The use of common and scientific names throughout the text follows Moss (1994).

\section{HABITAT}

Small-flowered sand verbena is found in dry habitats, particularly in loose sands of dune and

\footnotetext{
* See Appendix 5 for definitions of selected status designations.
}

sandhill areas. Some element of active (drifting) sand is usually required. The largest populations are on hard-packed finer sand on level terrain, but the species also occurs on south-, west-, and east-facing slopes and along dune ridge tops. Most Alberta sites are on the uplands, but sand verbena may also occur in the valleys of the Lost and South Saskatchewan rivers, where sand dunes extend down into the valleys. Common species associated with small-flowered sand verbena are sagebrush (Artemisia cana), needleand-thread grass (Stipa comata), sand grass (Calamovilfa longifolia), buckbrush (Symphoricarpos occidentalis), rose (Rosa acicularis), silverberry (Elaeagnus commutata), Indian rice grass (Oryzopsis hymenoides), scurf pea (Psoralea lanceolata), June grass (Koeleria macrantha), sand dropseed grass (Sporobolus cryptandrus), golden aster (Heterotheca villosa) and petiolate sunflower (Helianthus petiolaris). See Appendix 1 for a complete list of species that sand verbena is often found growing with.

Small-flowered sand verbena is found in the Dry Mixedgrass Subregion of the Grassland Natural Region in Alberta (Alberta Natural Heritage Information Centre 2002a). Climatically, the Dry Mixedgrass Subregion is the warmest and driest subregion in Alberta. It has a typical continental climate with cold winters, warm summers and low precipitation. Because of the warm summer temperatures and a high average wind speed, the rate of evaporation is high throughout the summer months. There is a high daily and seasonal temperature variation. This subregion is characterized by a year-round mean temperature of $4^{\circ} \mathrm{C}$ and a growing season (May - September) mean of about $16^{\circ} \mathrm{C}$. The mean winter temperature is typically about $-7^{\circ} \mathrm{C}$ (Anonymous 1997).

Total annual precipitation in the Dry Mixedgrass Subregion is typically around $260-280 \mathrm{~mm}$, and summer precipitation is lowest of any subregion in Alberta. As well, this subregion has relatively high year-to-year precipitation variability. Spring is the wettest season with about 
two-thirds of the annual precipitation falling as rain, and with the peak occurring in June. The amount of snow cover is relatively low, as is the number of days of continuous snow (Anonymous 1997).

See Appendix 2 for site-specific habitat information for Purple Springs (Site 5), Grassy Lake (Site 6), Lower Bow (Site 11), North of Medicine Hat (Site 12), and North of Medicine Hat Suffield (Site 14). No specific habitat information was found for Lost River (Sites 13), Purple Springs (Site 4 only), Wolf Island (Site 7), Lower Bow (Sites 8-10 only), North of Medicine Hat (Site 13 only), or Suffield National Wildlife Area (Site 15).

\section{CONSERVATION BIOLOGY}

\section{General. - Small-flowered sand verbena is} an annual species and a member of the four o'clock family (Nyctaginaceae), so named because the flowers tend to open in the late afternoon. It is a much-branched plant, 20-50 $\mathrm{cm}$ high, with trailing branches up to $60 \mathrm{~cm}$ long, with ascending tips. The rooting system is a taproot. The succulent, pale stems are enlarged at the nodes. The paired leaves have smooth margins, are somewhat round, and have prominent veins. Leaf blades are $2-6 \mathrm{~cm}$ long and $1-3 \mathrm{~cm}$ wide. The tiny greenish-white flowers are arranged in dense clusters with a ring of bracts underneath. Flowers lack petals, but have 5 petal-like lobes formed into a long tube, $5 \mathrm{~mm}$ in width. When the ovary ripens into the fruit, the base of the flower tube becomes transformed into a winged structure, closely enclosing the fruit and aiding in its dispersal. The dry seed-like fruits are surrounded by 2 or 3 wide, papery, conspicuously veined wings that are $20 \mathrm{~mm}$ long (Kershaw et al. 2001). These winged fruits are pale green with a pink blush.

Small-flowered sand verbena superficially resembles wild begonia or sand dock (Rumex venosus), but wild begonia is a perennial plant with stout (not brittle), erect stems; its flowers are borne in leafy, branched clusters at the stem tip with no sheathing stipules (leaf-like structures). Young small-flowered sand verbena plants sometimes resemble members of the goosefoot family in shape, colour and mealiness (of the underside of the leaves) (Kershaw et al. 2001). Sometimes the soft salmon-pink colour of the old flowers of prickly-pear (Opuntia fragilis) and scarlet mallow (Sphaeralcea coccinea) can mimic the similar colour of smallflowered sand verbena fruits (COSEWIC 2002a).

There are no other indigenous species of the genus Tripterocalyx in Alberta with which to confuse small-flowered sand verbena. The only other species of Tripterocalyx native to Canada is Tripterocalyx latifolia Eschsch., which is restricted to southwestern British Columbia. This species cannot be confused with smallflowered sand verbena as it has yellow flowers and fruits that are less than $1.5 \mathrm{~cm}$ in length.

2. Reproduction. - Small-flowered sand verbena is an ephemeral (short-lived) species. Flowering occurs from May to July over the range of the species, but at Canadian sites occurs mostly in the middle of June with fruit set in mid-July. On July 12, 2002 small-flowered sand verbena was in full flower at the Grassy Lake, Purple Springs and Lower Bow sites (COSEWIC 2002a). Fruit was light salmon-pink and almost fully developed. Flowers and fruit tend to be present at the same time earlier in the season. On September 2 of the same year most plants were past the flowering stage, and had dropped masses of seeds on the ground directly below the plant. Only a few individuals were still in immature fruit and flower on September 2. No data are available on pollination mechanisms of sand verbena.

Normally, perennial-dominated plant communities of arid regions, such as sandhills and deserts, become open to invasion by annuals during brief periods of excess soil moisture. To 
be successful in this type of habitat, an annual plant must promptly respond to favorable growing conditions, reproduce abundantly, and return to a dormant state (seed) awaiting the next opportunity. Warm spring temperatures, coupled with favorable soil moisture conditions resulting from snow melt and seasonal precipitation, bring on rapid phenological development to maturity. Death of the mature plant ensues when summer temperatures and surface soil moisture conditions become critical (Evans and Thames 1981).

Ephemerals such as small-flowered sand verbena usually germinate in the spring. They grow quickly, flower and produce seeds before dying and scattering their progeny to the sandy floor. This is a very successful adaptation to arid conditions as the plants survive the heat, and often drought, of midsummer as dormant seeds. These seeds are extremely hardy. The plants survive in this way until the following spring, sometimes two or three springs, when they repeat the cycle (Danin 1996).

Annuals commonly exhibit rapid germination of seeds, a high seed germination rate, rapid extension of primary root systems, and high vigor in seedlings. The growth of plants in arid habitats is directly related to the availability of moisture. Hence, the timing of the availability of moisture is extremely important (Evans and Thames 1981).

With all annuals there is an ever-present danger that germination may be triggered by precipitation from a storm of short duration, and the resulting highly vulnerable seedling crop is killed in a subsequent hot, dry period. Germination of seeds of most annuals (most likely including small-flowered sand verbena) is inhibited by biochemical controls so they are delayed in germination until this danger period has passed (Evans and Thames 1981).

Small-flowered sand verbena has a seed that is enclosed by a persistent winged structure.
Moisture is required to leach substances from these wings or promote fungal growth and hence mechanical softening. These processes allow the seed to become separated so that germination may occur unimpeded by the winged structure. Therefore, germination will also depend not only on the total rainfall but also on the duration. A slow rain brings on more germination through the leaching effect on seeds than does a sudden, heavy rainfall yielding the same precipitation total. Temperatures also interact strongly with precipitation (Evans and Thames 1981). Exact effects of temperature and precipitation on the reproductive processes of small-flowered sand verbena requires further study.

3. Survival. - Small-flowered sand verbena is superbly adapted for survival within its sand dune habitat. Most arid plant adaptations are focussed on increasing the ability of the plant to obtain and maintain moisture levels that are necessary for survival. The low, shrub-like form of the plant's canopy and silhouette is typical of species that have been adapted to trap fine silts and clays, as a result of lower wind velocities within the canopy and around the base of the plant (Danin 1996). Silt and clay have a higher water-holding capability than fine to coarse sand, and this silt/clay can absorb early morning dews more efficiently (Danin 1996).

The stems, leaves, and roots of small-flowered sand verbena are also adapted in a variety of ways to ensure the survival of the plant in arid conditions. The rigid stems of small-flowered sand verbena offers protection from desiccation. The stems of this plant are viscid (with sand adhering to the surface), which insulates them from abrasive hazards such as airborne sand. Lower surfaces of leaves may have a similar coating. Leaves also are fairly thick and simple in form offering a reduction in leaf area and decreasing potential water loss (Danin 1996). Also, the smooth upper surface and erect form of the leaf may direct condensation from early morning dews to the root system (Welsh 1987). 
The formation of a viable seed bank is vital for the future survival of the species within its sandy habitat. Directed wind dispersal of the fruit of dune species enables them to remain in their most appropriate sites and avoid being carried off the dunes to non-sandy sites unsuitable for seed germination. The wind causes the fruit to roll or glide, eventually stopping on leeward slopes of dunes, where wind velocity approaches zero. The fruit is covered by sand during future wind depositions. As the leeward slope slowly moves forward, new fruits are deposited in new leeward slopes. Consequently, the entire dune area becomes a seed bank at all depths. Seeds remain in the system of mobile sand protected from animals. Exposed fruit may move with strong winds to nearby areas where correct moisture and temperature regimes result in germination (Danin 1996). More study is required to determine the longevity of viable seeds of sand verbana within the seed bank.

\section{Movements/Dispersal. - The fruit of small-} flowered sand verbena, an achene (a small, dry, one-seeded fruit that does not open), has three thin wings that facilitate dissemination. The fruit, seeds and seed dispersal system are all fully adapted for survival within arid habitats. The winged fruit may roll on the ground or float well on water. Hairs are absent on fruits because they would impede wind dispersal during rolling or gliding on sandy surfaces (Danin 1996). The wings on these fruits aid dispersal by the gusty winds of sand dune fields (Kershaw et al. 2001). It is likely that seeds establish downwind or downstream from the original sites, as a result of wind or water dissemination. Two past investigators (Hudson 1982, Johnson and Hallworth 1975) located additional populations by following this logic. No specific information on seed dispersal distance is available for this species; hence, little is known about the potential for movement between populations.

5. Horticultural Use. - Small-flowered sand verbena has no known commercial uses. Many species of the genus Tripterocalyx have horticultural use in borders, rockeries and baskets. No specific horticultural information was obtained for small-flowered sand verbena.

\section{DISTRIBUTION}

1. Alberta. - Small-flowered sand verbena is known from eight general locations in southeastern Alberta, some of which contain multiple sites and subsites: Lost River (3 sites), Purple Springs ( 2 sites), Grassy Lake (1 site), Wolf Island (1 site), Lower Bow (4 sites), North of Medicine Hat (2 sites), North of Medicine Hat Suffield (1 site) and Suffield National Wildlife Area (1 site) (Figure 1, Appendix 3A). The proximity of sites within the same general location may indicate that some or all of the sites actually belong to the same population, but this can only be confirmed by genetic analysis. In the absence of genetic information, ANHIC defines a plant population as being separated by roughly $1 \mathrm{~km}$ or more (K. Vujnovic, pers. comm.), therefore, using this definition, the general locations are likely considered separate populations, except for possibly Purple Springs (location 2) and Grassy Lake (3). Dry conditions and strong winds may have a significant influence on dispersal of species such as smallflowered sand verbena. For example, the two sites $(12,13)$, that compose the North of Medicine Hat general location, are less than 2 $\mathrm{km}$ apart. The Lower Bow general location contains four sites (8-11) that are 1-2 km apart. The Purple Springs general location contains two sites that are separated by $3 \mathrm{~km}$. The Lost River general location includes three sites (1-3); Site 2 is approximately $2 \mathrm{~km}$ southeast of Site 1, and Site 3 is approximately $6 \mathrm{~km}$ southeast of Site 2. All three sites are linked by their preference for habitat bordering the eastern Lost River.

The Alberta sites all occur within an area northeast of the town of Bow Island (at the confluence of the Bow, Oldman and South Saskatchewan rivers), east to the Saskatchewan border and south to the Montana border, at 


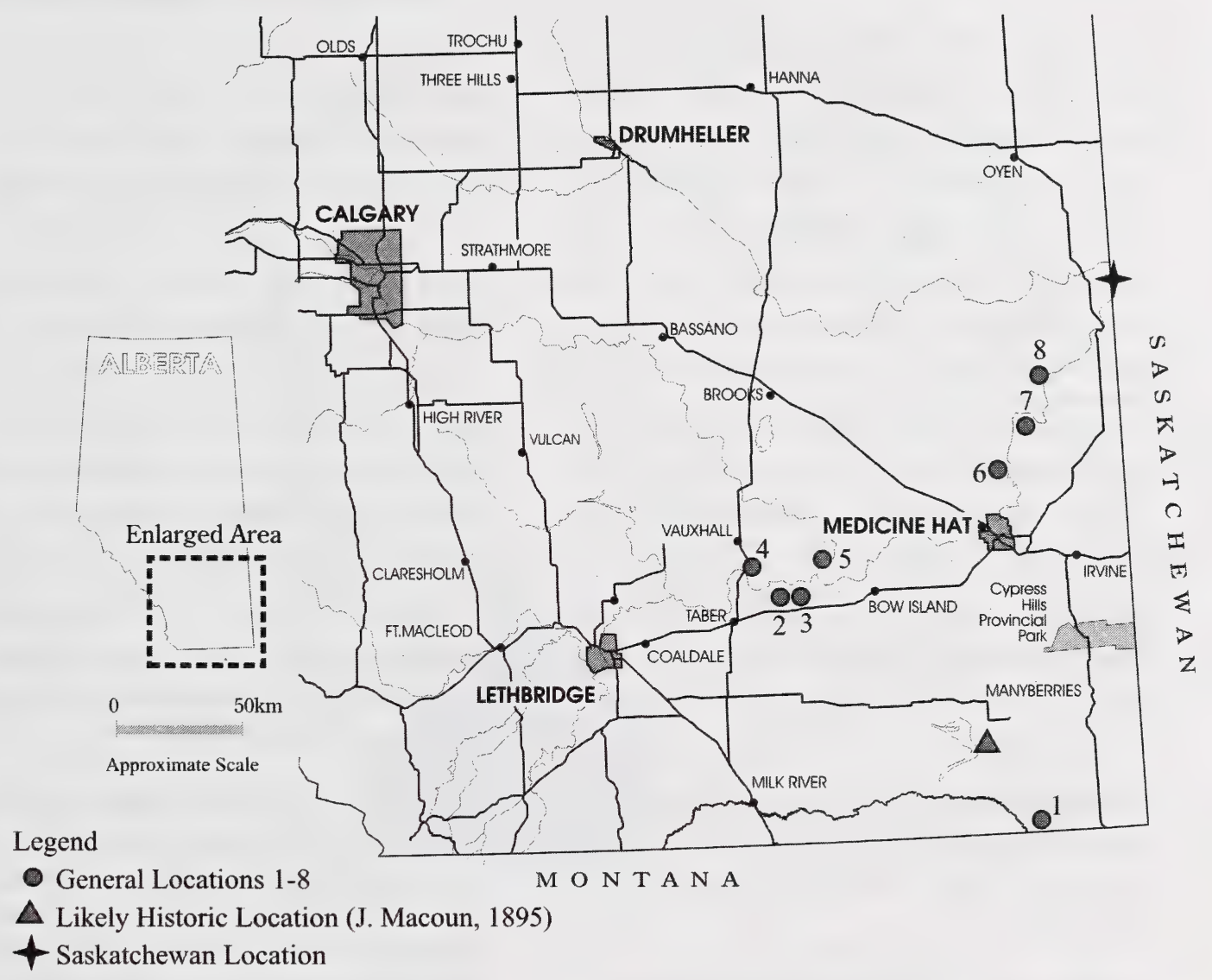

Figure 1. Distribution of small-flowered sand-verbena (Tripterocalyx micranthus) in Alberta and Saskatchewan, representing the total Canadian distribution of this species. General locations of the species in Alberta are as follows: 1. Lost River, 2. Purple Springs, 3. Grassy Lake, 4. Wolf Island, 5. Lower Bow, 6. North of Medicine Hat, 7. North of Medicine Hat Suffield, and 8. Suffield National Wildlife Area. Some general locations contain multiple sites and subsites. 
widely scattered localities (Figure 1). Smallflowered sand verbena is always associated with a river system in Alberta. Seven of the eight locations are associated with the South Saskatchewan River. One location is associated with the Lost River near the border with Montana.

Historically, small-flowered sand verbena has been located at the crossing of Manyberries Creek north of Milk River (1895) by John Macoun (Appendix 3B). An attempt was made to relocate this site in 1992 and again in 2002, but the site has never been pinpointed (Smith and Bradley 1992, COSEWIC 2002a). Manyberries Creek joins Pakowki Lake north of the Milk River. Macoun's site could be at any point along this creek and could possibly occur in the Pakowki Lake sand dunes, which would provide suitable habitat. Small-flowered sand verbena has never been reported from the Pakowki Lake sand dunes. Manyberries Creek is found approximately $40 \mathrm{~km}$ northwest of Lost River (site 2), close to the American border. The closest American site for small-flowered sand verbena is found in eastern Montana, a distance greater than the dispersal capability of this species.

No other locations have been found for this species despite ongoing surveys within the sandy areas of southern Alberta by a variety of investigators.

2. Other Areas. - In Saskatchewan, the species occurs at only one site just east of the Alberta border, where the South Saskatchewan River bends into Saskatchewan and out again to join the Red Deer River (Hudson 1982) (Figure 1, Appendix 3C). This site is located just southeast of the town of Empress, Alberta.

Small-flowered sand verbena is a species of western North America (Figure 2). In the United States, small-flowered sand verbena is distributed in eastern Montana, Nebraska, Wyoming, Utah, Colorado, Nevada, eastern
California, northern Arizona, New Mexico, North Dakota, South Dakota, western Kansas and northern Texas. There is no information on the potential for immigration and gene flow between populations in Montana and Alberta.

\section{POPULATION SIZE AND TRENDS}

1. Alberta. - In 2002, new sites were located at Purple Springs (Site 5, 269 plants), Grassy Lake (Site 6, 1797 plants), Lower Bow (Site 11, 789 plants), North of Medicine Hat (Site 12, 99 plants) and North of Medicine Hat Suffield (Site 14, 1 plant). At the Lower Bow, Grassy Lake and Purple Springs locations, the majority of plants were reproductive in 2002 (i.e., $>90 \%$ in fruit and $5 \%$ in flower in September). The total population of Alberta plants counted during the summer 2002 field season was 2955 plants. The total Alberta population of small-flowered sand verbena is estimated to contain 3600 plants, based on population data from 2002 and previous years. This population estimate likely represents a maximum along a wide continuum of population sizes for sand verbena in Alberta. See Appendices 3 and 4 for details of the known sand verbena records in Alberta.

In the original COSEWIC status report (Smith and Bradley 1992), small-flowered sand verbena was known from five sites in Alberta: Lost River, Purple Springs, Wolf Island, Lower Bow and North of Medicine Hat. At that time, the total Alberta population was estimated to contain approximately 1000 plants. Population numbers may fluctuate dramatically on an annual basis, most likely as a result of precipitation levels. For example, in 2001, a drought year, only one plant was found at Lower Bow (Site 11) (B. Smith, unpubl. data), but in 2002 the same location contained 789 plants. This demonstrates that a more realistic estimate of the population is presented, given the nature of this species, by reporting population levels over a number of years rather than from a single seasonal occurrence (see Appendices 3 and 4). 


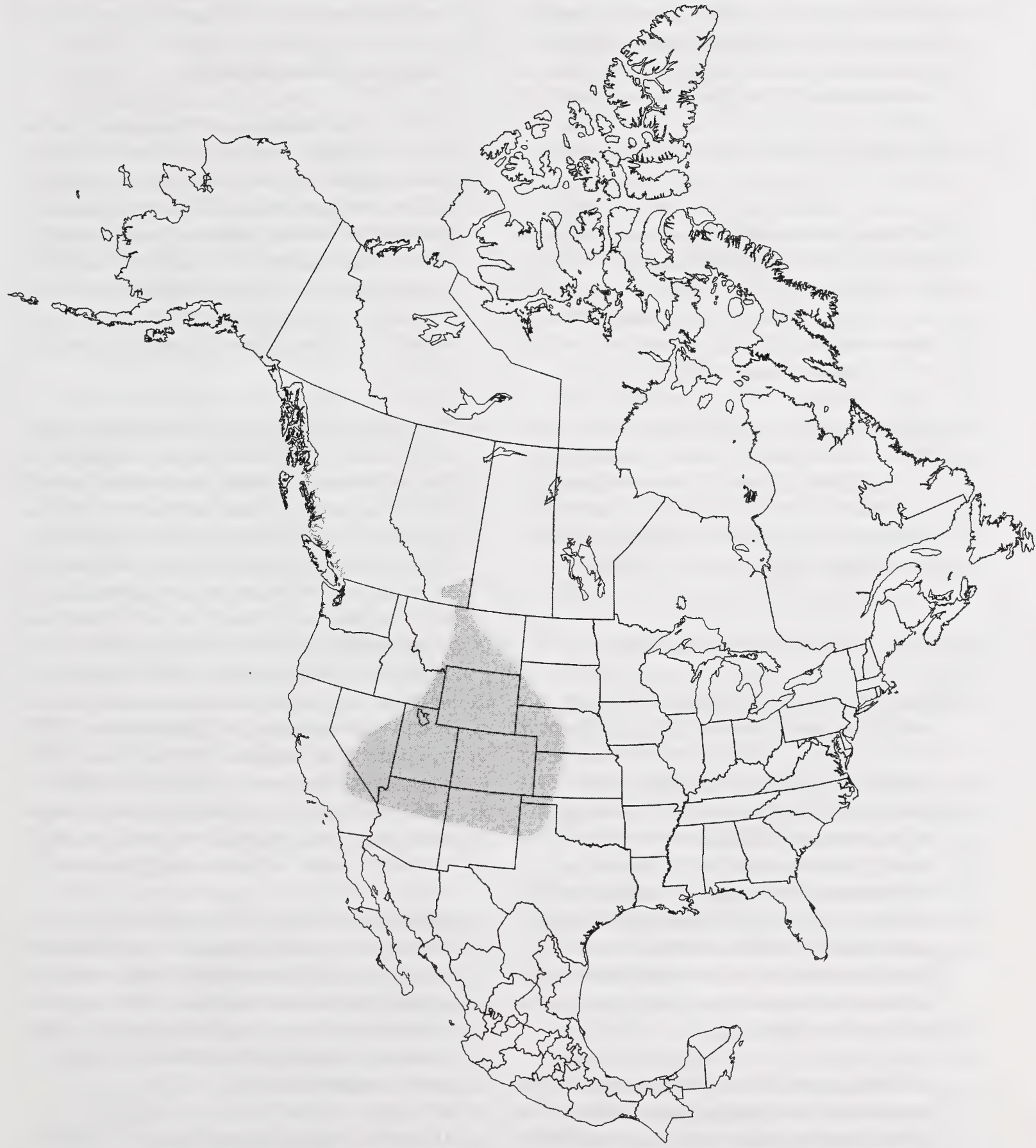

Figure 2. North American distribution of small-flowered sand-verbena (Tripterocalyx micranthus). 
2. Other Areas. - Only one other Canadian small-flowered sand verbena site exists outside Alberta, just east of the Alberta/Saskatchewan border along the South Saskatchewan River in Saskatchewan. John H. Hudson located 10 plants at this site in 1981 and described it as a steep sloping cutbank on loose sand (Hudson 1982).

The Saskatchewan site was surveyed (by Sheila Lamont and Wayne Harris) in August 2002, but no small-flowered sand verbena plants were found at that time. An abundance of other annuals was noted during the survey of the dune area (C. Elchuk, pers. comm.).

It is considered "not rare" in most states, except Nebraska and Kansas, where it is considered rare, and South Dakota, where it is thought to be extirpated (Kershaw et al. 2001). No specific population information is available for smallflowered sand verbena in the United States.

\section{LIMITING FACTORS}

Background: The Grasslands Natural Region is one of the most threatened natural regions in Alberta. Over two-thirds of the Dry Mixedgrass Subregion has been cultivated or otherwise developed (Anonymous 1997). Many major sandplains (essential habitat for small-flowered sand verbena) have disappeared and many others are threatened (Wallis 1988). Essential habitat is defined by Wallis (1987) as "most crucial to the survival of population, species, races or form. When these essential habitats are disturbed there will be major effects on the plants and animals that depend on them."

In Alberta, about $20 \%$ of the rare plants in the grassland and parkland regions are found in sandy soils, principally in sandhill areas (Wallis 1987). Sandhill areas are locally distributed, and diverse sandhill areas are rare. Common threats to plants in these habitats are trampling by cattle, and invasion of non-native species as a result of vegetation reclamation along oil and gas access roads and well-sites (Wallis 1987).

\section{General Limiting Factors:}

1. Dune Stabilization. - A number of studies have noted the ongoing process of dune stabilization over the past 50 years, in both Alberta and Saskatchewan (Epp and TownleySmith 1980, Wallis 1988, Wallis and Wershler 1988). Documented loss of habitat has been established in the Middle Sandhills in Alberta, as well as the Dundurn, Harris and Great Sandhills in Saskatchewan (Smith and Bradley 1992).

The main limiting factor affecting smallflowered sand verbena is its narrow preference for unstabilized sites within dune fields. Indeed, the single greatest threat to the survival of this species in Canada is habitat loss as a result of the process of dune stabilization from the encroachment of vegetation on active dunes, a process that has allowed various prairie and weedy species to overtake the open sandy habitat necessary for the survival of small-flowered sand verbena. Large areas of once-active sand have been stabilized since the 1940s (Wallis 1988); in several sandy sites in Alberta, Wallis (1988) reported a reduction in active sand of between $30 \%$ and $90 \%$. If the current trends continue, rare native sand dune plants, such as smallflowered sand verbena, which now have dangerously low populations, could be eliminated entirely (Wallis and Wershler 1988). There has apparently been an overall dramatic loss of sandy habitat over the Canadian range of small-flowered sand verbena. This long-term process could be reversed with climatic changes or through human interference with selective dune destabilization.

It would take several years of dune destabilization to restore necessary habitat for the survival of small-flowered sand verbena. Habitat has simply been lost; dune surfaces have been stabilized by various other species resulting 
from the absence of both fire and browsing by American bison (Bos bison) over the Canadian prairies. Grazing by other species, such as pronghorn (Antilocapra americana) and deer, does not affect sandy habitat in the same way. Browsing by American bison retarded shrub growth on sandy areas, impeding the process of dune stabilization. As well, trampling and winter bedding areas used by American bison aided in creating and maintaining active sandy blowouts. It is possible that small-flowered sand verbena will disappear over its Canadian range in a relatively short time period, if the process of dune stabilization is not somehow reversed.

Ironically, stabilization of the active dunes was, and continues to be, seen as good land conservation practice. To minimize erosion, land managers attempt to stabilize active blowouts by extinguishing fires, modifying their grazing patterns, and even placing old tires in the blowouts (Wallis and Wershler 1988, T. Hood, pers. comm.).

2. Changes in Land Use. - Historically, suitable habitat has been lost as a direct result of farming practices. Several major sandplains have been almost completely cultivated and a major threat exists to the remaining habitats (Wallis 1988). The process of cultivation of areas surrounding the known small-flowered sand verbena sites does not allow the spread of the species to surrounding areas.

The Lower Bow location, previously containing the largest Canadian population of smallflowered sand verbena, is fully engaged as an oilfield with extensive roadways, transmission lines, well-sites and active exploration and oilfield activities. In effect, this activity has destabilized the sand in several dune areas allowing for creation of suitable habitat for the species. In one instance, small-flowered sand verbena was found growing on a road cut at the Lower Bow location. However, this potentially positive effect must be countered with the physical loss of habitat within the dune field, which is now used for facilities and roads. The area of gas and oilfield activities is bounded by the Bow and Oldman rivers at their confluence with the South Saskatchewan River to the north, south and east, and agricultural land to the west.

Sand removal is occurring at the Grassy Lake and Lower Bow locations. This activity is especially heavy at the Grassy Lake location, where heavy equipment is being used to level the main dune and spread the sand on the surrounding prairie in the process of road building or gasfield activities. Sand removal or severe disturbance of the main dune will likely result in a full or partial destruction of the seed bank. Without the seed bank the species will not be able to resurge during climatically favourable years. This process should be halted or at least closely monitored. This activity is endangering the integrity of this most populous site for small-flowered sand verbena. Evidence of removal of sand by hand (bucket) was observed at the Lower Bow location.

All-terrain vehicle (ATV) use of the dune slopes at the Purple Springs location may result in damage to individual plants of small-flowered sand verbena.

3. Invasion of Weedy Species. - There is the potential for invasion of non-native species as a result of vegetation reclamation along oil and gas access roads and well-sites. Part of the Lower Bow dune is being stabilized by Russian thistle (Salsola kali), bee plant (Cleome serrulata) and foxtail barley (Hordeum jubatum) (Wallis 1987). Most of the natural vegetation at the Lower Bow location has been lost as a result of oil and gasfield activities. Within the gasfield there has been considerable habitat lost as a result of the great abundance of introduced weedy species including the following: crested wheat grass (Agropyron pectiniforme), flixweed (Descurainia sophia), sand rocket (Diplotaxis muralis), red-root pigweed (Amaranthus retroflexus), and lamb's-quarters (Chenopodium album). 
Site-specific Limiting Factors in 2002:

\section{Purple Springs (Site 5). - Threats to survival} of small-flowered sand verbena at this site include the following: 1) cattle trampling of plants, and 2) ATV or vehicle use. Cattle grazing was very light in July; however, by September, the area was very trampled. Use of ATVs or vehicles on the steep north dune slopes had killed several plants. The area has been used as a party site and beer bottles litter the north slope where bank swallows occur. Potential site damage should be monitored.

2. Grassy Lake (Site 6). - Threats to survival of small-flowered sand verbena at this site include the following: 1) sand removal, 2) trampling of plants by cattle, and 3 ) the access road that runs through the habitat. Sand is being actively removed from this site for road-building or other purposes. On September 2, 2002, it was noted that considerable amounts of sand had been removed from the dune area. As well, sand has been spread and flattened over areas southeast of the dune, resulting in the burial of some plants in the area of the pipeline that runs north to south from the gas battery (150 $\mathrm{m}$ from the dune). Burial of plants this late in the season may result in minimal damage, as small-flowered sand verbena fruit goes through periods of burial and exposure by winds and rain. Removal of sand is a serious threat to the sustainability of the species at this site, because sand removal compromises the seed bank for the species. Vehicle travel on the access road to the sand dune was killing plants by driving over them. Several dozen small-flowered sand verbena were noted to be growing on the access road (two-track) to the site. Twelve plants were observed to be severely damaged on July 12 , and the damage was found to be continuing on September 2.

\section{Lower Bow (Site 11). - Threats to the survival} of small-flowered sand verbena were noted: 1) oil and gasfield activities, including facilities and roads, 2) introduction of weedy species, 3 ) agricultural practices, including trampling by cattle and direct habitat loss through cultivation, and 4) removal of sand. The most immediate intervention required is halting the removal of sand for personal use, which is a direct threat to the security of small-flowered sand verbena habitat at this site. Although weedy species (especially green tansy mustard) were present, habitat loss has occurred as a result of dune stabilization by both native and weedy species. Furthermore, the effects of cattle grazing on the processes of dune stabilization should be examined. It is possible the destabilization resulting from this activity is helpful to the maintenance of habitat.

\section{STATUS DESIGNATIONS*}

\section{Alberta. - The Alberta Natural Heritage} Information Centre (ANHIC) ranks smallflowered sand verbena as S2 (Vujnovic and Gould 2002). The species is considered "May Be At Risk", according to the General Status 2000 exercise conducted by Alberta Sustainable Resource Development (Alberta Sustainable Resource Development, unpubl. report). Alberta's Wildlife Act addresses protection of plant species at risk; however, no status designations for plants have yet been assigned under this Act.

2. Other Areas. - Small-flowered sand verbena was assigned a status of "Threatened" by the Committee on the Status of Endangered Wildlife in Canada (COSEWIC) in 1992, based on the information in the original status report written for the species (Smith and Bradley 1992). In 2002, the status designation was reviewed by COSEWIC and upgraded to "Endangered". Harms et al. (2001) ranks small-flowered sand verbena as "Endangered" in Saskatchewan. No specific legal status is accorded small-flowered sand verbena in any part of Canada. The Natural Heritage Status ranks are: Global G5, Canada

\footnotetext{
*See Appendix 5 for definitions of the status designations referred to in this section.
} 
N2, United States N? (rank unknown), and Saskatchewan S1. The ranks for each state are as follows: Arizona (SR), California (S1.3), Colorado (SR), Kansas (S1), Montana (SR), Nebraska (S1), Nevada (SR), New Mexico (SR), North Dakota (SR), South Dakota (SH), Utah (SR) and Wyoming (S3) (NatureServe Explorer 2002).

\section{RECENT MANAGEMENT IN ALBERTA}

All Alberta locations occur on Crown land presently under grazing (Purple Springs, Wolf Island, North of Medicine Hat) or oil/gas leasehold (Grassy Lake, Lower Bow). The Lost River general location lies on Dominion Experimental Farm land presently used for grazing cattle. Sites 12 (North of Medicine Hat), 14 (North of Medicine Hat Suffield) and 15 (Suffield National Wildlife Area) are located within Canadian Forces Base Suffield. No information on land use was presented by Macdonald (1997) in his report on the wildlife area. The Saskatchewan site occurs on Crown land used for grazing cattle.

There is currently no active management of the species or its habitat in either Alberta or Saskatchewan.

\section{SYNTHESIS}

There are nine known Canadian locations where small-flowered sand verbena grows, eight of which are in Alberta. There is one other Canadian location in Saskatchewan, near the Alberta border on the South Saskatchewan River. However, no plants were found at this location during the 2002 field season. Smallflowered sand verbena was assigned the status "Threatened" by COSEWIC in 1992 (Smith and Bradley 1992). At that time, a Canadian population of fewer than 1000 individuals was estimated, the majority of which were in Alberta. In 2002, COSEWIC upgraded the status designation to "Endangered", because there is only a small number of widely dispersed, small populations that fluctuate greatly with annual precipitation levels.

Although the population can resurge given proper climatic conditions, notably high precipitation levels, such as those experienced in 2002, the population can also crash in a drought year, such as 2001 . Hence, population counts for the species fluctuate widely from yearto-year. For example, a low of 1 plant was recorded in 2001 (at 1 site, within 5 general locations surveyed), whereas a high of 2955 plants was recorded in 2002 (at 5 sites, within 6 general locations surveyed).

All sites cover discrete, small areas of $100 \mathrm{~m}^{2}$ or less. In most cases, there is no other nearby potential habitat into which the species could spread. One exception is the Purple Springs sandhill area, which covers approximately 10 $\mathrm{km}^{2}$. Within this sandhill area, small-flowered sand verbena is known from only three sites (Purple Springs, 2 sites; Grassy Lake, 1 site) none of which cover more than $100 \mathrm{~m}^{2}$. For unknown reasons, the species is apparently unable to take advantage of seemingly similar habitat.

Small-flowered sand verbena requires actively blowing sand for formation of seedbeds for future germination prospects. As a result of dune stabilization, there are very few exposed sandy areas remaining in Alberta. Small-flowered sand verbena is not found on all such sandy areas, but on only a limited few. The process of dune stabilization is reducing the expanse of even these few areas and habitat loss is ongoing. Sand removal is occurring at two of the Alberta locations, namely, Lower Bow (Site 11) and Grassy Lake (Site 6). In 2002, the Grassy Lake location contained over $50 \%$ of the known Alberta population for the species. However, sand removal at this site is extensive and ongoing, and the main dune is in the process of being levelled. This presents a direct threat to the most populous Canadian site for the species. 
There are also agricultural and industrial impacts that affect the species and its habitat, particularly the introduction of invasive weedy species. Introduction of weedy species is particularly extensive at the Lower Bow location. Extensive weed introduction at the Lower Bow (Site 11) gasfield site has led to a direct loss of possible habitat, such that there is little weed-free habitat remaining there. Potential habitat is restricted to the small areas near the Bow River. All other areas within the expansive Bow gasfield are crisscrossed by numerous roads, inundated by weedy species, irrigated by farmers near the Oldman River or dotted by gas facilities.
Little is known about most aspects of smallflowered sand verbena's ecology. Research is required on its seed ecology, including longevity of viable seeds in the seed bank, germination requirements, and seed dispersal distance. Research is required on the effects of climatic influences, cattle grazing and dune stabilization on overall population levels and survival rates. A multi-year study on population variability would be useful in assessing the ongoing status of the species within Alberta. 


\section{LITERATURE CITED}

Alberta Sustainable Resource Development. 2001. The General Status of Alberta Wild Species 2000. Alberta Sustainable Resource Development, Fish and Wildlife Service, Edmonton, AB. 46 pp.

Alberta Sustainable Resource Development. Unpubl. report. Vascular Plants: 2000 Preliminary General Status Ranks for Alberta. Alberta Sustainable Resource Development, Fish and Wildlife Division, Edmonton AB.

Alberta Natural Heritage Information Centre. 2002a. Natural Regions and Subregions of Alberta. URL: http:// www.cd.gov.ab.ca/preserving/parks/ anhic/natural_regions_map.asp. (Updated October 2002).

Alberta Natural Heritage Information Centre. 2002b. Database search for Tripterocalyx micranthus (Torr.) Hook. Alberta Natural Heritage Information Centre, Edmonton.

Alberta Natural Heritage Information Centre. 2002c. Rank Definitions. URL: http:// www.cd.gov.ab.ca/preserving/parks/ anhic/definit.asp [Revision date: October 2002].

Anonymous. 1997. The Grassland Natural Region of Alberta. Alberta Environmental Protection, Government of Alberta, Edmonton. 229 pp. plus appendices.

COSEWIC 2002a. Draft of update status report on sand verbena (Tripterocalyx micranthus (Torr.) Hook.) prepared for COSEWIC by Bonnie Smith. Committee on the Status of Endangered Wildlife in Canada, Ottawa. 15 pp.
COSEWIC. 2002b. COSEWIC status assessments - November 2002. Committee on the Status of Endangered Wildlife in Canada. URL: http:// www.cosepac.gc.ca/htmlDocuments/ Detailed_Species_Assessment_e.htm.

COSEWIC 2002c. Committee on the Status of Endangered Wildlife in Canada. URL: http://www.cosewic.gc.ca. (Updated January 2002).

Danin, A. 1996. Plants of desert dunes. Edited by J.L. Cloudsley-Thompson. SpringerVerlag, Berlin. 177 pp.

Epp, H.T. and L. Townley-Smith, eds. 1980. The Great Sand Hills of Saskatchewan. Policy, Planning and Research Branch, Saskatchewan Department of the Environment, Regina. 156 pp.

Evans, D. D. and J.L. Thames. 1981. Water in desert ecosystems. US/IBP Synthesis Series II. Dowden, Hutchinson and Ross, Inc., Stroudsburg. 280 pp.

Harms, V. L., P. A. Ryan, and J. A. Haraldson. 2001. The rare and endangered native plants of Saskatchewan. W.P. Fraser Herbarium, University of Saskatchewan, Saskatoon. Data base search for Tripterocalyx micranthus references.

Hudson, J. H. 1982. Plant finds in Saskatchewan, 1980 and 1981. Blue Jay 40(3):136-138.

Johnson, H. and B. Hallworth. 1975. Further discoveries of small-flowered sand verbena in Alberta. Blue Jay 33(1):1315.

Kershaw, L., J. Gould, D. Johnson, and J. Lancaster. 2001. Rare vascular plants of Alberta. University of Alberta Press, 
Edmonton and Natural Resources Canada, Canadian Forestry Service, Northern Forestry Centre, Edmonton.484 pp.

Macdonald, I. D. 1997. Vascular plant flora component report Canadian Forces Base Suffield National Wildlife Area wildlife inventory. Canadian Wildlife Services, Edmonton. 209 pp.

Moss E. H. 1994. Flora of Alberta. Second edition, revised by John G. Packer. University of Toronto Press, Toronto, Canada.

National Research Council. 1995. Science and the Endangered Species Act. National Academy Press, Washington, DC. 271 pp.

NatureServe Explorer: An online encyclopedia of life [web application]. 2002. Version 1.6 Arlington, Virginia, USA: NatureServe. Available: http:// www.natureserve.org/explorer. (Date last updated: October 2002).

Smith, B.M. and C. Bradley. 1992. Status report on the small-flowered sand verbena Abronia micrantha Torr. Committee on the Status of Endangered Wildlife in Canada (COSEWIC), Ottawa. $17 \mathrm{pp}$.

Trottier, Garry. 2002. Field incident report sand verbena CFB Suffield. August 29, 2002. Canadian Wildlife Service, Edmonton.
Vujnovic, K. and J. Gould, comp. 2002. Alberta Natural History Information Centre tracking and watch lists-vascular plants, mosses, liverworts and hornworts. Alberta Community Development, Parks and Protected Areas Division, Edmonton.

Wallis, C. A. 1987. Critical, threatened and endangered habitats in Alberta, pp. 4963, in Proceedings of the workshop on endangered species in the prairie provinces by Geoffrey L. Holroyd et al. Provincial Museum of Alberta Natural History Occasional Paper No. 9, Edmonton.

Wallis, C. A. 1988. The Unsung benefits of wind erosion - stabilizing sand dunes spell trouble for rare plants. Iris Newsletter 3:1-2.

Wallis, C. A. and C. Wershler. 1988. Rare wildlife and plant conservation studies in sandhill and sandplain habitats of southern Alberta. Alberta Forestry, Lands and Wildlife; Alberta Recreation and Parks; World Wildlife Fund Canada, Edmonton. 161 pp.

Welsh, S. L. 1987. A Utah flora. Edited by N.D. Atwood, S. Goodrich and L.C. Higgins. Great Basin Naturalist Memoirs No. 9. Brigham Young University, Provo. 894 pp. 
Appendix 1: Plant species found growing with small-flowered sand verbena in 2002, including those species listed in the Habitat section of the report.

annual lupine (Lupinus pusillus)

ascending purple milk vetch (Astragalus striatus)

bee plant (Cleome serrulata)

brittle prickly-pear (Opuntia fragilis)

buckbrush (Symphoricarpos occidentalis)

common blue lettuce (Lactuca pulchella)

common goat's-beard (Tragopogon dubius)

common pepper grass (Lepidium densiflorum)

common wild rose (Rosa woodsii)

cushion cactus (Coryphantha vivipara)

dotted blazing star (Liatris punctata)

golden aster (Heterotheca villosa)

golden bean (Thermopsis rhombifolia)

green tansy mustard (Descurainia pinnata)

harebell (Campanula rotundifolia)

Indian rice grass (Oryzopsis hymenoides)

June grass (Koeleria macrantha)

low goldenrod (Solidago missouriensis)

needle-and-thread grass (Stipa comata)

pasture sagewort (Artemisia frigida)

petiolate sunflower (Helianthus petiolaris)

prairie onion (Allium textile)

prostrate amaranth (Amaranthus graecizans)

ridge-seeded spurge (Euphorbia glyptosperma)

rose (Rosa acicularis)

Russian thistle (Salsola kali)

sagebrush (Artemisia cana)

sand dropseed grass (Sporobolus cryptandrus)

sand grass (Calamovilfa longifolia)

scarlet butterflyweed (Gaura coccinea)

scurf pea (Psoralea lanceolata)

shrubby cinquefoil (Potentilla fruticosa)

silverberry (Elaeagnus commutata)

skeletonweed (Lygodesmia juncea)

small-leaved everlasting (Antennaria parvifolia)

spiny ironplant (Haplopappus spinulosus)

wavy-leaved thistle (Cirsium undulatum)

wild licorice (Glycyrrhiza lepidota)

wormseed mustard (Erysimum cheiranthoides) 
Appendix 2: Site-specific habitat information for sites surveyed in 2002: Purple Springs (Site 5), Grassy Lake (Site 6), Lower Bow (Site 11), North of Medicine Hat (Site 12), and North of Medicine Hat Suffield (Site 14).

\section{Purple Springs (Site 5):}

Small-flowered sand verbena was located on a very large, mostly stabilized dune just east of the access road. The dimensions of the northeast-running dune were $250 \mathrm{~m}$ by $70 \mathrm{~m}$. The dune rises $4 \mathrm{~m}$ above the surrounding prairie, but 6-7 $\mathrm{m}$ above the inner dune flats. There are only small areas of exposed sand. Sand verbena plants at this site cover less than $100 \mathrm{~m}^{2}$ (likely closer to $50 \mathrm{~m}^{2}$ ).

There are three sandy blow-outs and two bank swallow nest sites. Typical small-flowered sand verbena plants at Purple Springs are 10-15 cm in height, occurring on southeast-facing slopes with sagebrush, scurf pea, goosefoot (Chenopodium sp.), green tansy mustard and Fendler's cryptanthe (Cryptantha fendleri). Common goat's-beard, cocklebur (Xanthium strumarium), Russian thistle and golden aster were common on lower dunes. Western bluebur, common pepper grass, ridge-seeded spurge, green tansy mustard, Pursh's plantain (Plantago purshii) and blue grama (Bouteloua gracilis) were common on open sandy areas.

\section{Grassy Lake (Site 6):}

A sizable dune, $25 \mathrm{~m}$ length by $5 \mathrm{~m}$ width rising $6 \mathrm{~m}$ from the surrounding plain, dominates this site. The large dune is adjoined by a fairly open sandy plain covering an area of approximately $100 \mathrm{~m}$ by 50 $\mathrm{m}$. Sand verbena plants at this site cover approximately $100 \mathrm{~m}^{2}$. Dominant species on the sandplain near the open dune are sagebrush and scurf pea. There are areas of $50 \%$ open sand in and amongst these two species. A species of the fungus Endoptychum is common on the open sandy areas.

Proceeding east away from the open dune, the habitat becomes grassier with sagebrush, scurf pea, green needlegrass (Stipa viridula), bee plant, Pursh's plantain, common pepper grass, wormseed mustard, common wild rose, and sand dock (very occasional). In the flatter areas on the sandplain as you approach the prairie the following species become common: blue grama, Fendler's cryptanthe, wild licorice, sagebrush, Pursh's plantain, pasture sagewort, low milk vetch (Astragalus lotiflorus) and wild tomato (Solanum triflorum).

\section{Lower Bow (Site 11):}

The site lies within a small field of partly stabilized sand dunes located along the southern shore in a bend of a small tributary brook flowing into the Bow River. At this site, small-flowered sand verbena is restricted to an area of approximately $100 \mathrm{~m}^{2}$ in the partly stabilized dune, typically of a $10 \%-15 \%$ grade and rising 3-4 $\mathrm{m}$ from the surrounding prairie. Small-flowered sand verbena was not found on lower dunes. The presence of bank swallow nests on the steep sand walls may indicate the presence of small-flowered sand verbena. Bank swallow nests were found at the Lower Bow and Purple Springs sites. The inner dune flats of dune circles have no small-flowered sand verbena plants. Steep rises and exposed sand are apparently necessary habitat characteristics. Where sand verbena typically grows, there is some element of drifting sand, and $20 \%$ to $50 \%$ of barren sand is exposed. The sand hills at Lower Bow, although mostly stabilized by grasses and other vegetation, still contain small areas of drifting sand. 
Sandy areas increase in size and frequency nearer to the Bow River, although land use in areas immediately adjacent to the Bow, and especially, the Oldman rivers, are agricultural in nature, including irrigation farming. The majority of the natural vegetation was found in the northeastern area of the gas field. The increased rainfall experienced in this area during the summer of 2002 has resulted in weedy species attaining heights of 1 to $1.5 \mathrm{~m}$, compared to less than $1 \mathrm{~m}$ in 2001 .

The following species were frequently noted on the tops of the stabilized dunes: sagebrush, common wild rose, Fendler's cryptanthe, common pepper grass, scurf pea, goosefoot, needle-and-thread, green needlegrass, wormseed mustard, and Indian rice grass. Partly stabilized open dune slopes were characterized by scurf pea, annual lupine and bee plant. Dune flats were characterized by prairie sagewort (Artemisia ludoviciana), low goldenrod, annual lupine and golden aster.

In 2001, one plant was found on a road that had exposed, actively blowing sand and was mostly devoid of any other vegetation (B. Smith, unpubl. data). The occasional scurf pea, prostrate amaranth (Amaranthus graecizans) and Indian rice grass were located in the same area. Bee plant was common along roads in the gasfield.

\section{North of Medicine Hat (Site 12, Trottier 2002) \\ Subsite 12A - Fish Creek, CFB Suffield:}

Small-flowered sand verbena was found on a low active dune adjacent to the rim of the steep-eroding channel bank of the river. The dune is about $140 \mathrm{~m}$ long and on average $35 \mathrm{~m}$ wide, overlooking the South Saskatchewan River. Plants were also on the adjoining flat, silty sand terrace extending south $15 \mathrm{~m}$ beyond a fenceline, and west to a fluvial ravine. One plant was found in the bottom of a shallow blowout with absolutely no other vegetation in the depression. The small dune complex was formed in spring 2002 by sand migration from blowouts.

In addition to those species mentioned in the general habitat, the following plant species were also found in association with the low active dune: Coupland's sunflower (Helianthus couplandii), northern bedstraw (Galium boreale), ground-plum (Astragalus crassicarpus), skunkbush (Rhus trilobata) and silverberry. Low sedge (Carex stenophylla), western wheat grass (Agropyron smithii), thread-leaved sedge (Carex filifolia) and chokecherry (Prunus virginiana) were noted to occur on the silty soil terrace habitat.

\section{Subsite 12B - Down-river from subsite 12A:}

This subsite was located along a riparian fence on a gently sloping plain in a blue-grama, needle-andthread community, typically on loamy sand with a $2 \%-9 \%$ slope.

\section{Subsite 12C - Up-river from subside 12A:}

Low active dune superimposed on the terrace adjacent to the rim of the steep-eroding channel bank of the river. Plants were found on mostly unvegetated sand-dune blowout.

\section{North of Medicine Hat Suffield (Site 14) (Trottier 2002):}

This site was located on a low stabilized dune complex on an undulating plain containing well-drained sand to loamy sand with stones and boulders. Small-flowered sand verbena was found on a stabilized dune crest. The plant community was typical of that described for subsite $12 \mathrm{~A}$ and contained many of the plant species described in the general habitat section. 
Appendix 3: Details of small-flowered sand verbena records for the following: A\&B) Alberta, and C) Saskatchewan.

A. Current Alberta records (after Alberta Natural Heritage Information Centre 2002b):

\begin{tabular}{|c|c|c|c|c|c|}
\hline $\begin{array}{l}\text { General } \\
\text { Location }\end{array}$ & Site \# & $\begin{array}{c}2002 \\
\text { Population }\end{array}$ & $\begin{array}{c}\text { Other } \\
\text { Population }\end{array}$ & Date & Collector \\
\hline 1. Lost River & $\begin{array}{l}2 \\
3\end{array}$ & & $\begin{array}{c}200 \\
\text { approx. } 100 \\
\text { no count } \\
\text { no count }\end{array}$ & $\begin{array}{c}\text { May 28, } 1985 \\
2000 \\
\text { July 6, } 1979 \\
\text { July 6, } 1972\end{array}$ & $\begin{array}{l}\text { Wallis, Clifford } \\
\text { (2 subsites) } \\
\begin{array}{c}\text { C. Wallis, pers. } \\
\text { comm. }\end{array} \\
\begin{array}{c}\text { S.T.G. (full name } \\
\text { not known) }\end{array} \\
\text { Sharp, W.H. }\end{array}$ \\
\hline 2. Purple Springs & $\begin{array}{l}4 \\
5 \\
\end{array}$ & 269 & 30 & $\begin{array}{c}1987 \\
\text { July } 13,2002 \\
\end{array}$ & $\begin{array}{c}\text { Wallis, C. } \\
\text { Smith, Bonnie M. }\end{array}$ \\
\hline 3. Grassy Lake & 6 & 1797 & & July 12,2002 & Smith, B.M. \\
\hline 4. Wolf Island & $\begin{array}{l}\text { 7, subsite A } \\
7, \text { subsite B }\end{array}$ & & $\begin{array}{l}100 \\
10 \\
\end{array}$ & $\begin{array}{l}1987 \\
1987 \\
\end{array}$ & $\begin{array}{l}\text { Wallis, C. } \\
\text { Wallis, C. }\end{array}$ \\
\hline 5. Lower Bow & $\begin{array}{c}8 \\
9 \\
10 \\
11\end{array}$ & 789 & $\begin{array}{c}12 \\
250 \\
3 \\
1\end{array}$ & $\begin{array}{c}1987 \\
1987 \\
1987 \\
2001 \\
\text { July } 12,2002\end{array}$ & $\begin{array}{l}\text { Wallis, C. } \\
\text { Wallis, C. } \\
\text { Wallis, C. } \\
\text { Smith, B.M. } \\
\text { Smith, B.M. }\end{array}$ \\
\hline $\begin{array}{l}\text { 6. North of } \\
\text { Medicine Hat }\end{array}$ & $\begin{array}{c}12 \text {, subsite } A \\
12 \text {, subsite } B \\
12 \text {, subsite C } \\
13\end{array}$ & $\begin{array}{l}78 \\
19 \\
2\end{array}$ & $<100$ & $\begin{array}{c}2002 \\
2002 \\
2002 \\
\text { July } 19,1972\end{array}$ & $\begin{array}{c}\text { Trottier, Garry } \\
\text { Trottier, G. } \\
\text { Trottier, G. } \\
\text { Johnson, Hope } \\
\text { (also July 22, } \\
\text { 1973) }\end{array}$ \\
\hline $\begin{array}{l}\text { 7. North of } \\
\text { Medicine Hat } \\
\text { Suffield }\end{array}$ & 14 & 1 & & 2002 & Trottier, G. \\
\hline $\begin{array}{c}\text { 8. Suffield } \\
\text { National Wildlife } \\
\text { Area }\end{array}$ & 15 & 0 & 1 & $\begin{array}{c}\text { June } 18,1994 \\
2002\end{array}$ & $\begin{array}{l}\text { Macdonald, Ian } \\
\text { Trottier, G. }\end{array}$ \\
\hline $\begin{array}{l}8 \text { general } \\
\text { locations }\end{array}$ & 15 sites & 2955 & $\begin{array}{c}706 \\
\text { (approximate) }\end{array}$ & & \\
\hline
\end{tabular}


B. Historical Alberta record (only incomplete information available):

Crossing of Manyberries Creek, north of Milk River, on sand; John Macoun (No. 12902); July 9, 1895; National Museum of Canada record CAN 50677.

\section{Saskatchewan record:}

LSD 11 in 5-22-29 w $^{\text {rd }}$, steep sloping cutbank on loose sand; John H. Hudson (No. 4152); July 11, 1981; SASK 72881. Duplicate in University of Regina herbarium (\#7573). 
Appendix 4: Site-specific population information for A) sites where sand verbena plants were recorded in 2002 (Purple Springs, Grassy Lake, Lower Bow, North of Medicine Hat, and North of Medicine Hat Suffield), and B) sites where no plants were found in 2002 (Wolf Island, Purple Springs Site 4 only).

\section{A) Sites where sand verbena was recorded in 2002:}

\section{Purple Springs (Site 5):}

Small-flowered sand verbena occurs in three locales along the large main dune. The western dune area, containing $30 \%$ open sand, has 60 plants along the upper dune on open sand. The southern dune area contains a $30-\mathrm{m}$ stretch of blowouts and open sand associated with bank swallow nest site and has 197 plants. The northern dune area contains a $10-\mathrm{m}^{2}$ area of exposed sand with bank swallow nest sites and has 12 plants. Total population counted was 269 plants.

Typical small-flowered sand verbena plants in the northern dune area are 10-15 cm in height. Plants on the southern dune area are 0.6 to $1 \mathrm{~m}$ in diameter, at their largest.

\section{Grassy Lake (Site 6):}

This site contains the largest known Alberta population of small-flowered sand verbena (1797 plants), and is therefore of vital importance for ensuring the survival of the species in Alberta. Plants are found on a dune that rises $6 \mathrm{~m}$ from the surrounding plain, and on the surrounding sandy plain. Of the 1797 plants found at this site, 570 plants were found on the sand dune ( 60 of these on the open northeast dune face, the remainder on the dune crest and upper southwest-facing dune slopes). The surrounding sandy plain contained 1227 plants (1070 of these south of the access road to the dune, the remainder north of the access road). Small-flowered sand verbena disappears as the prairie becomes more stabilized with grasses and other herbs.

The site is small in size, approximately $100 \mathrm{~m}$ (north to south) by $40 \mathrm{~m}$ (east to west). Small-flowered sand verbena occurs with considerable density especially around and under the edges of sagebrush on the open sandy plains east of the sand dune. Plants on open sand can become 1-1.5 $\mathrm{m}$ in width, which is very large in comparison to other sites investigated during the 2002 field season.

\section{Lower Bow (Site 11):}

The population is distributed in three locales within a small dune field composed of about a dozen dunes. The total population found on the western dune is 293 plants. An additional 2 plants were located on the portion of this dune separated from the remainder of the dune by the access road. The eastern dune contained 494 plants. In total, the Lower Bow site contained 789 plants.

Plants are not evenly distributed on the dunes. On the western dune, plants are concentrated along a 10 $\mathrm{m}$ by $20 \mathrm{~m}$ strip on the southern dune area. Of the 293 plants found on this dune, 266 plants are located within this area. Of these 266 plants, 247 plants were found on the dune slopes and 19 along the dune crest. The remaining 27 plants are scattered along the northern dune crest. No plants were found along the lower dune slopes or crests. On the eastern dune, 407 of the 494 plants were located within a southwest sandy blowout as well as along dune crests. The remaining 87 plants were distributed along the dune slopes above the inner dune circle. Typically, small-flowered sand verbena is found on higher slopes of partly stabilized dune areas. Usually, there is significant open sand at these sites. 


\section{North of Medicine Hat (Site 12):}

In 2002, a new site on Canadian Forces Base Suffield, north of Medicine Hat was discovered. (Garry Trottier, pers. comm., September 2002). Trottier discovered three nearby subsites with a total population count of 99 plants. The population counts for these sites were as follows: subsite 12A (Fish Creek): 78 plants in groupings of 48, 29 and 1 plants; subsite 12B (Down-river from subsite 12A): 19 plants in groupings of 17 and 2 plants; and subsite $12 \mathrm{C}$ (Up-river from subsite 12A): 2 plants.

\section{North of Medicine Hat Suffield (Site 14):}

Another new site on Canadian Forces Base Suffield, north of Medicine Hat, was discovered in 2002, some $22 \mathrm{~km} \mathrm{~N}$ of site 12 (G. Trottier, pers. comm., 2002). Only one plant was found.

\section{B) Sites surveyed in 2002 with no sand verbena plants recorded:}

\section{Lost River (Site 1):}

The proper Lost River site was not located, although several nearby areas were surveyed by the author (August 31, 2002). In later communication with C. Wallis, who discovered the original site, the author realized she missed the site by approximately $1 \mathrm{~km}$ or less, turning south toward the Lost River instead of continuing west toward the Lost River site.

Small-flowered sand verbena had been observed at this site in 2001 or 2000 . The site is less than 100 $\mathrm{m}^{2}$ in total area and consists of a few old, partially stabilized sand blowouts (C. Wallis, pers. comm.).

\section{Wolf Island (Site 7):}

Sand verbena was first observed here by C. Wallis in 1987 (Wallis and Wershler 1988). The area north of the site was typified by wild begonia/sand dock, sagebrush $(1.2 \mathrm{~m})$ and common wild rose. The area is badly infested with downy chess (Bromus tectorum) and severely trampled by cattle. The area south of the site was typified by badland near the Oldman River. Wild begonia/sand dock was scattered on river banks. No potential sites were noted on either the north or south approach. All surrounding areas were agricultural. This site was not relocated and may be lost as a result of the process of dune stabilization. The Wolf Island site is apparently fully stabilized and contains no functioning habitat. It may be possible, however, that there are seeds in the seed bank that would germinate if the area was redisturbed.

\section{Purple Springs}

One of the Purple Springs Sandhills sites surveyed during 2002 was an area containing three northeastrunning $\left(\mathrm{N} 48^{\circ} \mathrm{E}\right)$ dunes adjacent to the Oldman River. These sandhills were typified by the following species: wild begonia/sand dock, sagebrush (0.6-1 m), Indian rice grass, wormseed mustard, scurf pea, Fendler's cryptanthe, bee plant, green needlegrass, wheat grass (Agropyron trachycaulum), goosefoot (Chenopodium pratericola), skeletonweed, common wild rose, and ridge-seeded spurge. Taller shrubs were found on the dune tops and backs, whereas it was more grass-dominated in dune hollows (wild licorice, wheat grass, pasture sagewort, sagebrush). Although this area contained habitat that was apparently suitable for small-flowered sand verbena, no plants were found during the author's 2001 or 2002 surveys. Wild begonia/sand dock is common on sandy soils to the apparent exclusion of smallflowered sand verbena. 
Several additional sites were investigated within the Purple Springs dune field that extends southwest from the above site toward the town of Purple Springs. All were covered with wild begonia/sand dock, often heavily trampled by cattle. Only two good sandy sites with small-flowered sand verbena were discovered within the dune field (described as the Grassy Lake and Purple Springs small-flowered sand verbena sites in this report), although several other sites were surveyed. There are yet other potential sites within the dune field that should be surveyed. Time limitations and distance to these dune sites did not allow them to be surveyed in the 2002 field season. 
Appendix 5. Definitions of selected legal and protective designations.

A. The General Status of Alberta Wild Species 2000 (after Alberta Sustainable Resource Development 2001)

\begin{tabular}{|c|c|c|}
\hline 2000 Rank & 1996 Rank & Definitions \\
\hline At Risk & Red & $\begin{array}{l}\text { Any species known to be "At Risk" after formal detailed status } \\
\text { assessment and designation as "Endangered" or "Threatened" in } \\
\text { Alberta. }\end{array}$ \\
\hline May Be At Risk & Blue & $\begin{array}{l}\text { Any species that may be at risk of extinction or extirpation, and is } \\
\text { therefore a candidate for detailed risk assessment. }\end{array}$ \\
\hline Sensitive & Yellow & $\begin{array}{l}\text { Any species that is not at risk of extinction or extirpation but may } \\
\text { require special attention or protection to prevent it from becoming } \\
\text { at risk. }\end{array}$ \\
\hline Secure & Green & $\begin{array}{l}\text { Any species that is not "At Risk", "May Be At Risk", or } \\
\text { "Sensitive". }\end{array}$ \\
\hline Undetermined & $\begin{array}{l}\text { Status } \\
\text { Undetermined }\end{array}$ & $\begin{array}{l}\text { Any species for which insufficient information, knowledge or data } \\
\text { is available to reliably evaluate its general status. }\end{array}$ \\
\hline Not Assessed & $\mathrm{n} / \mathrm{a}$ & $\begin{array}{l}\text { Any species known or believed to be present but which has not yet } \\
\text { been evaluated. }\end{array}$ \\
\hline Exotic/Alien & $\mathrm{n} / \mathrm{a}$ & $\begin{array}{l}\text { Any species that has been introduced as a result of human } \\
\text { activities. }\end{array}$ \\
\hline Extirpated/Extinct & $\mathrm{n} / \mathrm{a}$ & $\begin{array}{l}\text { Any species no longer thought to be present in Alberta } \\
\text { ("Extirpated") or no longer believed to be present anywhere in the } \\
\text { world ("Extinct"). }\end{array}$ \\
\hline Accidental/Vagrant & $\mathrm{n} / \mathrm{a}$ & $\begin{array}{l}\text { Any species occurring infrequently and unpredictably in Alberta, } \\
\text { i.e., outside their usual range. }\end{array}$ \\
\hline
\end{tabular}

\section{B. Alberta Wildlife Act/Regulation}

Species designated as "Endangered" under Alberta's Wildlife Act include those listed as "Endangered" or "Threatened" in the Wildlife Regulation.

\begin{tabular}{|l|l|}
\hline Endangered & A species facing imminent extirpation or extinction. \\
\hline Threatened & A species that is likely to become endangered if limiting factors are not reversed. \\
\hline
\end{tabular}

\section{Committee on the Status of Endangered Wildlife in Canada (after COSEWIC 2002c)}

\begin{tabular}{|l|l|}
\hline Extinct & A species that no longer exists. \\
\hline Extirpated & A species that no longer exists in the wild in Canada, but occurs elsewhere. \\
\hline Endangered & A species facing imminent extirpation or extinction. \\
\hline Threatened & A species that is likely to become endangered if limiting factors are not reversed. \\
\hline Special Concern & $\begin{array}{l}\text { A species of special concern because of characteristics that make it particularly } \\
\text { sensitive to human activities or natural events. }\end{array}$ \\
\hline Not at Risk & A species that has been evaluated and found to be not at risk. \\
\hline Data Deficient & $\begin{array}{l}\text { A species for which there insufficient scientific information to support status } \\
\text { designation. }\end{array}$ \\
\hline
\end{tabular}


D. Heritage Status Ranks: Global (G), National (N), Sub-National (S) (after Alberta Natural Heritage Information Centre 2002c)

\begin{tabular}{|l|l|}
\hline G1/N1/S1 & $\begin{array}{l}5 \text { or fewer occurrences or only a few remaining individuals. May be especially } \\
\text { vulnerable to extirpation because of some factor of its biology. }\end{array}$ \\
\hline G2/N2/S2 & $\begin{array}{l}\text { 6-20 or fewer occurrences or with many individuals in fewer locations. May be } \\
\text { especially vulnerable to extirpation because of some factor of its biology. }\end{array}$ \\
\hline G3/N3/S3 & $\begin{array}{l}\text { 21-100 occurrences, may be rare and local throughout its range, or in a restricted range } \\
\text { (may be abundant in some locations). May be susceptible to extirpation because of } \\
\text { large-scale disturbances. }\end{array}$ \\
\hline G4/N4/S4 & Typically $>100$ occurrences. Apparently secure. \\
\hline G5/N5/S5 & Typically $>100$ occurrences. Demonstrably secure. \\
\hline GX/NX/SX & Believed to be extinct or extirpated, historical records only. \\
\hline GH/NH/SH & Historically known, may be relocated in future. \\
\hline GR/NR/SR & Reported, but lacking in documentation \\
\hline
\end{tabular}

E. United States Endangered Species Act (after National Research Council 1995)

\begin{tabular}{|l|l|}
\hline Endangered & $\begin{array}{l}\text { Any species which is in danger of extinction throughout all or a significant portion of } \\
\text { its range. }\end{array}$ \\
\hline Threatened & $\begin{array}{l}\text { Any species which is likely to become an endangered species within the foreseeable } \\
\text { future throughout all or a significant portion of its range. }\end{array}$ \\
\hline
\end{tabular}




\section{List of Titles in This Series}

(as of May 2003)

No. 1 Status of the Piping Plover (Charadrius melodus) in Alberta, by David R. C. Prescott. 19 pp. (1997)

No. 2 Status of the Wolverine (Gulo gulo) in Alberta, by Stephen Petersen. 17 pp. (1997)

No. 3 Status of the Northern Long-eared Bat (Myotis septentrionalis) in Alberta, by M. Carolina Caceres and M. J. Pybus. 19 pp. (1997)

No. 4 Status of the Ord's Kangaroo Rat (Dipodomys ordii) in Alberta, by David L. Gummer. 16 pp. (1997)

No. 5 Status of the Eastern Short-horned Lizard (Phrynosoma douglassii brevirostre) in Alberta, by Janice D. James, Anthony P. Russell and G. Lawrence Powell. 20 pp. (1997)

No. 6 Status of the Prairie Rattlesnake (Crotalus viridis viridis) in Alberta, by Sheri M. Watson and Anthony P. Russell. 26 pp. (1997)

No. 7 Status of the Swift Fox (Vulpes velox) in Alberta, by Susan E. Cotterill. 17 pp. (1997)

No. 8 Status of the Peregrine Falcon (Falco peregrinus anatum) in Alberta, by Petra Rowell and David P. Stepnisky. 23 pp. (1997)

No. 9 Status of the Northern Leopard Frog (Rana pipiens) in Alberta, by Greg Wagner. 46 pp. (1997)

No. 9 Update 2003. Status of the Northern Leopard Frog (Rana pipiens) in Alberta. Alberta Sustainable Resource Development. 61 pp. (2003)

No. 10 Status of the Sprague's Pipit (Anthus spragueii) in Alberta, by David R. C. Prescott. 14 pp. (1997)

No. 11 Status of the Burrowing Owl (Speotyto cunicularia hypugaea) in Alberta, by Troy I. Wellicome. 21 pp. (1997)

No. 12 Status of the Canadian Toad (Bufo hemiophrys) in Alberta, by Ian M. Hamilton, Joann L. Skilnick, Howard Troughton, Anthony P. Russell, and G. Lawrence Powell. 30 pp. (1998)

No. 13 Status of the Sage Grouse (Centrocercus urophasianus urophasianus) in Alberta, by Cameron L. Aldridge. 23 pp. (1998)

No. 14 Status of the Great Plains Toad (Bufo cognatus) in Alberta, by Janice D. James. 26 pp. (1998)

No. 15 Status of the Plains Hognose Snake (Heterodon nasicus nasicus) in Alberta, by Jonathan Wright and Andrew Didiuk. 26 pp. (1998)

No. 16 Status of the Long-billed Curlew (Numenius americanus) in Alberta, by Dorothy P. Hill. 20 pp. (1998)

No. 17 Status of the Columbia Spotted Frog (Rana luteiventris) in Alberta, by Janice D. James. 21 pp. (1998)

No. 18 Status of the Ferruginous Hawk (Buteo regalis) in Alberta, by Josef K. Schmutz. 18 pp. (1999)

No. 19 Status of the Red-tailed Chipmunk (Tamias ruficaudus) in Alberta, by Ron Bennett. 15 pp. (1999)

No. 20 Status of the Northern Pygmy Owl (Glaucidium gnoma californicum) in Alberta, by Kevin C. Hannah. 20 pp. (1999) 
No. 21 Status of the Western Blue Flag (Iris missouriensis) in Alberta, by Joyce Gould. 22 pp. (1999)

No. 22 Status of the Long-toed Salamander (Ambystoma macrodactylum) in Alberta, by Karen L. Graham and G. Lawrence Powell. 19 pp. (1999)

No.23 Status of the Black-throated Green Warbler (Dendroica virens) in Alberta, by Michael R. Norton. 24 pp. (1999)

No. 24 Status of the Loggerhead Shrike (Lanius ludovicianus) in Alberta, by David R. C. Prescott and Ronald R. Bjorge. 28 pp. (1999)

No. 25 Status of the Plains Spadefoot (Spea bombifrons) in Alberta, by Richard D. Lauzon. 17 pp. (1999)

No. 26 Status of the Trumpeter Swan (Cygnus buccinator) in Alberta, by M. Lynne James. 21 pp. (2000)

No. 27 Status of the Pygmy Whitefish (Prosopium coulteri) in Alberta, by William C. Mackay. 16 pp. (2000)

No. 28 Status of the Short-eared Owl (Asio flammeus) in Alberta, by Kort M. Clayton. 15 pp. (2000)

No.29 Status of the Willow Flycatcher (Empidonax traillii) in Alberta, by Bryan Kulba and W. Bruce McGillivray. 15 pp. (2001).

No. 30 Status of the Woodland Caribou (Rangifer tarandus caribou) in Alberta, by Elston Dzus. 47 pp. (2001)

No.31 Status of the Western Spiderwort (Tradescantia occidentalis) in Alberta, by Bonnie Smith. 12 pp. (2001)

No. 32 Status of the Bay-breasted Warbler (Dendroica castanea) in Alberta, by Michael Norton. 21 pp. (2001)

No.33 Status of the Cape May Warbler (Dendroica tigrina) in Alberta, by Michael Norton. 20 pp. (2001)

No. 34 Status of the Whooping Crane (Grus americana) in Alberta, by Jennifer L. White. 21 pp. (2001)

No. 35 Status of Soapweed (Yucca glauca) in Alberta, by Donna Hurlburt. 18 pp. (2001)

No. 36 Status of the Harlequin Duck (Histrionicus histrionicus) in Alberta, by Beth MacCallum. 38 pp. (2001)

No.37 Status of the Grizzly Bear (Ursus arctos) in Alberta, by John L. Kansas. 43 pp. (2002)

No. 38 Status of the Wood Bison (Bison bison athabascae) in Alberta, by Jonathan A. Mitchell and C. Cormack Gates. 32 pp. (2002)

No. 39 Status of the Bull Trout (Salvelinus confluentus) in Alberta, by John R. Post and Fiona D. Johnston. 40 pp. (2002)

No. 40 Status of the Banff Springs Snail (Physella johnsoni) in Alberta, by Dwayne A.W. Lepitzki. 29 pp. (2002)

No. 41 Status of the Shortjaw Cisco (Coregonus zenithicus) in Alberta, by Mark Steinhilber. 23 pp. (2002)

No. 42 Status of the Prairie Falcon (Falco mexicanus) in Alberta, by Dale Paton. 28 pp. (2002)

No. 43 Status of the American Badger (Taxidea taxus) in Alberta, by Dave Scobie. 17 pp. (2002)

No. 44 Status of the Yucca Moth (Tegeticula yuccasella) in Alberta. Alberta Sustainable Resource Development. 21 pp. (2002) 
No. 45 Status of the White-winged Scoter (Melanitta fusca deglandi) in Alberta. Alberta Sustainable Resource Development. 15 pp. (2002)

No. 46 Status of the Lake Sturgeon (Acipenser fulvescens) in Alberta. Alberta Sustainable Resource Development. 30 pp. (2002)

No. 47 Status of the Western Silvery Minnow (Hybognathus argyritis) in Alberta. Alberta Sustainable Resource Development. 24 pp. (2003)

No. 48 Status of the Small-flowered Sand Verbena (Tripterocalyx micranthus) in Alberta. Alberta Sustainable Resource Development. 24 pp. (2003) 
National Library of Canada
Bibliotheque

Bibliothèque nationale du Canada 